\title{
Dar forma ao impublicável: Carolina Maria de Jesus e sua arte
}

\author{
Shaping the Unpublishable: Carolina Maria de Jesus and her Art \\ Dar forma a lo impublicable: Carolina Maria de Jesus y su arte \\ Atilio Bergamini*
}

\section{Resumo}

Este artigo apresenta procedimentos estéticos que Carolina Maria de Jesus usou para tornar publicáveis, em Quarto de despejo, materiais que ela considerava impublicáveis. Tais procedimentos permitem conhecer alguns dos traços de um projeto estético e intelectual que parece ter orientado a escrita e a leitura de Carolina desde meados dos anos 1950 até sua morte em 1977.

Palavras-chave: Carolina Maria de Jesus, forma literária, fome, abolicionismo.

\begin{abstract}
This paper presents some aesthetic measures that Carolina Maria de Jesus took to make publishable materials that she considered unpublishable, in order to write Quarto de despejo. These methods reveal some of the features of an aesthetic and intellectual project, which have likely guided Carolina 's writing and reading since the mid 1950s until her death in 1977.
\end{abstract}

Keywords: Carolina Maria de Jesus, literary form, hunger, abolitionism.

\begin{abstract}
Resumen
Este artículo presenta los procedimientos estéticos que Carolina Maria de Jesus tomó para hacer publicables en Quarto de despejo materiales que ella consideraba impublicables. Tales procedimientos permiten conocer algunos de los rasgos de un proyecto estético e intelectual que parece haber orientado la escritura y la lectura de Carolina desde mediados de los años 1950 hasta su muerte en 1977.
\end{abstract}

Palabras-clave: Carolina Maria de Jesus, forma literaria, el hambre, abolicionismo.

\section{Publicar o impublicável}

A experiência de Carolina Maria de Jesus com a escrita e a leitura vinha de décadas quando o jornalista Audálio Dantas a encontrou na favela do Canindé, à beira do rio Tietê, em São Paulo, em 1955. Carolina aparecia em jornais desde pelo menos 1942, tentando publicar seus escritos e se tornar artista. A esse respeito, a escritora anotou:

Quando eu era empregada doméstica, trabalhava com má vontade, porque o meu desejo era ser artista. Queria ser cantora. Quando eu via uma artista no palco, invejava-a. Nos meus dias de folga lá estava eu, ou no teatro, ou nas rádios e na redação do Jornal O dia. Conversando com o saudoso Chico Sá, pôis pretendia ser escritora. Quando eu escrevia versos ia na redação para ouvir a opinião do senhor Francisco de Sá. Uma noite entrei na redação e disse: o senhor quer ouvir os últimos versos que escrevi? O senhor Francisco Sá coçou a Cabeça e disse-me: - oh, meu Deus! Porque é, que Eu não nasci surdo! (Fernandez, 2016, p. 12-3).

Desde essa época, Carolina era nomeada como poeta em diversos ambientes de São Paulo. Na favela, era conhecida pelos cadernos com que andava para cima e para baixo.

Quando ao longo dos anos 1940 ela mostrava seus cadernos para jornalistas, dava preferência a divulgar poemas e narrativas. Isso também aconteceu quando, por ocasião do primeiro encontro entre eles, Audálio Dantas pediu para Carolina mostrar o que tanto escrevia. Ela mostrou poemas, peças de teatro e prosa de fiç̧ão. Audálio perguntou por que Carolina não escrevia sobre os favelados e a

*Universidade Federal do Ceará (UFC), Fortaleza, CE, Brasil. (Dorcid.org/0000-0003-3613-373X. E-mail: atiliobergamini@gmail.com 
favela. Ela respondeu que escrevia, mas não para publicar. Desse desencontrado encontro de perspectivas a respeito do que era publicável, estabeleceu-se um pacto: Carolina passaria a escrever os diários para publicá-los (Meihy e Levine, 1994). "Eu não sou indolente", ela escreveu na entrada de 2 de maio de 1958 em Quarto de despejo. "Há tempos que eu pretendia fazer o meu diario. Mas eu pensava que não tinha valor e achei que era perder tempo" (Jesus, 1960, p. 25).

Portanto, a partir de 1955, Carolina se vê frente a um incômodo que diz respeito, entre outras questões, à técnica de escrita: transformar um material não publicável, sem valor, em um livro publicável, vendável, que tirasse a ela e a seus filhos da favela. Para Carolina, ao menos até o encontro com Audálio, as obras ficcionais mereciam ser publicadas; para Audálio o testemunho diário sobre a vida da favela teria mais valor. O curto-circuito entre ficção e testemunho, entre linguagem ficcional publicável e linguagem testemunhal impublicável (acrescentando que para Audálio ocorria o contrário: o ficcional era sem interesse de publicação, enquanto o testemunhal era interessante) parece ser um traço da escrita de Carolina no diário, especialmente a partir de 1958.

Vou, portanto, trabalhar com a hipótese de que Quarto de despejo pode ser lido como uma tentativa de Carolina tornar publicável (de acordo com seus próprios critérios) o que antes era impublicável (de acordo com seus próprios critérios). Como ela fez essa transição na técnica de sua escrita? Quais são as estruturas literárias que ela compõe para tornar publicável um texto para ela impublicável?

\section{Uma tradição e um projeto}

Além de escritora, Carolina foi uma leitora voraz. Dada a situação vulnerável em que viveu por anos, precisou se equilibrar entre ler tudo o que caia em sua mão e selecionar textos adequados aos propósitos que tinha - propósitos que vou expor nos próximos parágrafos. Tomo, para isso, o fio narrativo de Diário de Bitita, publicado pela primeira vez em francês, em 1977, a partir de uma edição problemática do material com o qual Carolina preparava suas memórias, que se intitulariam Um Brasil para brasileiros (Jesus, 2014, p. 13).

Carolina nasceu por volta de 1914 (ver Castro e Machado, 2007). Pelos idos de 1923, escutava leituras de O Estado de São Paulo, por meio das quais teria ficado sabendo de Rui Barbosa (Jesus, 2014, p. 44). Nietzsche a impressionava: a imprensa dizia que era débil mental, mas ele soubera prever diversas questões importantes, entre elas a fome do povo (Jesus, 2014, p. 51).

Pouco a pouco mapeou uma tradição antiescravista, na qual inscreveu o próprio nome: ela afirma que José Bonifácio, José do Patrocínio, Castro Alves, Luís Gama e Barão do Rio Branco não aceitavam a escravidão (Jesus, 2014, p. 54). “O povo era revoltado porque o seu sonho era aprender a ler, para ler o livro de Castro Alves" (Jesus, 2014, p. 62). E ainda: "[Eu] Queria ser igual ao José do Patrocínio, que ajudou a libertar os negros e ainda comprou um Ford" (Jesus, 2014, p. 97).

O Barão do Rio Branco a que se refere Carolina, talvez por associação ao confrade de Rui Barbosa, pode ser o pai do barão, o Visconde do Rio Branco, um dos articuladores da Lei do Ventre Livre, de 1871.

Carolina lê para não pensar na vida, mas pensa: encontra em Nietzsche uma reflexão sobre a fome do povo e monta uma tradição para si. Sobretudo, ela desmente, pela experiência, a ideia de que seria difícil ler, um achado e tanto num Brasil em que a escrita era tomada pelo beletrismo cacete e pela distinção de traços oligárquicos.

Quando descobriu que sabia ler, Carolina sentiu grande inquietação:

Vasculhei as gavetas procurando qualquer coisa para eu ler. A nossa casa não tinha livros. Era uma casa pobre. O livro enriquece o espírito. Uma vizinha emprestou-me um livro, o romance A escrava Isaura. Eu, que já estava farta de ouvir falar na nefasta escravidão, decidi que deveria ler tudo que mencionasse o que foi a escravidão. Compreendi tão bem o romance que chorei com dó da escrava. Analisei o livro. Compreendi que naquela época os escravizadores eram ignorantes, porque que quem é culto não escraviza, e os que são cultos não aceitam o jugo da escravidão. Era uma época de tête-à-tête porque uma pessoa culta prevê as consequências dos seus atos. Os brancos retirando os negros da África não previam que iam criar o racismo no 
mundo, que é problema e dilema. Eu lia o livro, retirava a síntese. E assim foi duplicando o meu interesse pelos livros. Não mais deixei de ler (Jesus, 2014, p. 129). ${ }^{1}$

Portanto, chama atenção de Carolina no romance de Bernardo Guimarães a reflexão a respeito da escravidão e da luta contra a escravidão. Por um lado, foi um acaso: a vizinha emprestou. Por outro, foi um desejo sustentado e longamente elaborado. Havia já formada para a escritora - ao menos para a Carolina adulta que recorda a Carolina menina - uma ideia construída depois de muita leitura e releitura, até "retirar uma síntese", e que parece persistir nas representações que ela fez de suas leituras: a tradição abolicionista, antiescravista, de luta contra a opressão sofrida pelos povos negros, fornecia os elementos básicos dos interesses de leitura, com problemas, autores e obras articulados por uma perspectiva estética e intelectual.

Nas horas vagas, eu lia Henrique Dias, Luís Gama, o mártir da Independência, o nosso Tiradentes. Todos os brasileiros atuais, e os do porvir, devem e deverão render preito ao saudoso Joaquim José da Silva Xavier. Não foi salteador, não foi pirata, foi um dos que também sonhou em preparar um Brasil para os brasileiros. Lendo, eu ia adquirindo conhecimentos sólidos (Jesus, 2014, p. 133).

É difícil saber se, nesse trecho, Carolina se refere a textos sobre Henrique Dias, Luís Gama e Tiradentes ou a textos escritos por eles (ou por alguns deles). Talvez se refira a um pouco das duas coisas. Seja como for que interpretemos a passagem, o Tiradentes herói nacional é ponto de chegada de outros dois heróis: Henrique Dias, negro, filho de africanos libertos, com presença ativa na resistência contra os holandeses durante o século XVII; e Luís Gama, o grande poeta, jornalista e advogado abolicionista, escravizado durante a infância, que apenas recentemente tem sido incorporado às reflexões sobre a literatura do século XIX. Como o título do livro seria Um Brasil para brasileiros, a presença dessa expressão no trecho se torna especialmente significativa: é uma evidência a mais de que a tradição que Carolina delineou se articula firmemente com seus projetos de escrita artística.

Os precursores listados por Carolina se relacionam diretamente à escravidão, à luta contra a escravidão e a uma perspectiva que procura perceber a presença negra na história do Brasil. A frase que se refere a Tiradentes, "Não foi salteador, não foi pirata, foi um dos que também sonhou em preparar um Brasil para os brasileiros", parece enfatizar Henrique Dias e Luís Gama: Tiradentes "também" sonhou em preparar o Brasil para os brasileiros. Os negros, como aconteceu com a mãe de Carolina, são presos constantemente, sem razão nenhuma, por ser bodes expiatórios (a esse respeito, logo trarei mais elementos), assim como foram presas e torturadas Carolina e sua mãe.

Não é de menor importância a visão de que o avô de Carolina, Benedito, seria, de acordo com ela, um "Sócrates africano" (Jesus, 2014, p. 122), a tal ponto ter sido um crime - na acepção mais brutal da palavra - não o educar. Ou seja, não há crime no que fazem Henrique Dias, Luís Gama, Tiradentes e tantos outros ao defender escravos e negros. Há crime em não permitir que uma pessoa como Benedito pudesse se educar. Esse avô tornou ainda mais viva a presença da escravidão nas reflexões de Carolina. Para completar, a escritora formulava uma espécie de compensação engenhosa: seu avô não pôde estudar, mas era muito culto, era um Sócrates. Ela mesma teve que seguir os estudos por conta própria, já que foi abandonada pelo país, mas era cada vez mais culta e lida. Por outro lado, quem escraviza é ignorante ou, para deixar ainda mais evidente, quem é culto não escraviza. Portanto, haveria um silogismo subterrâneo nessa maneira de Carolina narrar sua formação como leitora: culto é lutar contra a escravidão ao invés de promovê-la em pleno século XX.

Enquanto montava a base de seus interesses éticos e estéticos, Carolina seguiu lendo, ora o que aparecia, ora o que escolhia (e muitas vezes lendo o que escolhia naquilo que aparecia). A leitura de História sagrada, História universal e da Bíblia pode ter acontecido nos primeiros anos de alfabetização, a partir de empréstimos de uma professora (Jesus, 2014, p. 130). Num hospital, adoecida, a jovem Carolina leu A vida de santa Terezinha e de Santo Antônio (Jesus, 2014, p. 154). Ao sair do hospital, remexendo caixas de patrões, encontrou o que procurava: livros. O Dicionário

${ }^{1}$ Versão parecida aparece também em Meihy e Levine (1994, p. 198-219). 
prosódico, de João de Deus, destinado a quem desejasse aprender a falar "sem erros de pronúncia", passou a ser uma companhia constante (Jesus, 2014, p. 176).

Carolina narra:

Eu passava os dias lendo Os Lusíadas, de Camões, com o auxílio do dicionário. Eu ia intelectualizando-me, compreendendo que uma pessoa ilustrada sabe suportar os amarumes da vida [...] Por intermédio dos livros, eu ia tomando conhecimento das guerras que houve no Brasil, a guerra dos Farrapos, a guerra do Paraguai. Condenava essa forma brutal e desumana que o homem encontra para solucionar os seus problemas. Eu sentava no sol para ler. As pessoas que passavam, olhavam o dicionário e diziam: - Que livro grosso! Deve ser o livro de são Cipriano. Era o único livro que os incientes sabiam que existia e existe. Começaram a propalar que eu tinha um livro de são Cipriano. (...) Um dia estava lendo, passaram uns rapazes, pararam e pediram para ver o meu dicionário, entreguei o livro para eles olharem. Olharam e disseram: 'Ah, é mesmo o livro de são Cipriano. Como é pesado'. Percebi que eles eram pernósticos e fiquei com dó, porque a leitura beneficia tanto o homem como a mulher" (Jesus, 2014, p. 179-80).

Os jovens pernósticos deduram Carolina para um sargento, afirmando que ela acusava a polícia de prender somente os pobres. Carolina foi presa junto com sua mãe: "Você anda lendo o livro de são Cipriano. Pretende botar feitiço em quem?", perguntou o sargento, depois de Carolina ficar quatro dias fazendo trabalhos forçados. "Eu não creio no feitiço, e não tenho o livro de são Cipriano", disse Carolina. "Eu tenho", disse o sargento. Carolina descreve: "Eu gostava imensamente de livros e peguei o livro com carinho e cuidado, como se estivesse pegando uma criança recém-nascida. Mas estava nervosa para ler" (Jesus, 2014, p. 182). No quinto dia de prisão, Carolina lembra que o sargento pediu para que um soldado "preto" espancasse ela e sua mãe. "Ele nos espancava com um cacete de borracha. Minha mãe queria proteger-me, colocou o braço na minha frente recebendo as pancadas. O braço quebrou, ela desmaiou" (Jesus, 2014, p. 182).

O que apresentei até agora permite conclusões provisórias:

a) A memória de leitura de Carolina enfatiza uma tradição: Henrique Dias, José Bonifácio, José do Patrocínio, Castro Alves, Luís Gama e Barão do Rio Branco, Bernardo Guimarães, Rui Barbosa, Tiradentes. Haveria também Casimiro de Abreu, de quem Carolina leu As primaveras, criticamente referidas em Quarto de despejo, e Camões, de quem leu Os Lusíadas. A Bíblia, hagiografias e histórias de heróis nacionais parecem ser panos de fundo da formação dela, assim como revistas e jornais, a exemplo de O Estado de São Paulo, a partir dos quais construiu ideias a respeito de Rui Barbosa e Nietzsche (e talvez de Luís Gama e outros, figuras constantes em reportagens da época).

b) Escrever, para Carolina, significaria, entre outras coisas, tomar parte na tradição apontada. Nota-se que ao ser presa ela se coloca na posição de homens como Dias, Gama, Tiradentes, homens que Carolina identifica com seu avô, por terem sido julgados e criminalizados injustamente (assim como aconteceu com ela e sua mãe).

c) Muitas leituras surgem por acaso, dado o que está disponível, mas, a partir disso Carolina constrói projetos e propósitos nítidos, como, por exemplo, ler tudo o que aparecesse sobre a história da escravidão. Não por nada, a escravidão é um tema explícito e implícito de vários de seus escritos, incluindo os poemas. Por exemplo, o esquema escravista-inculto/ antiescravista-culto parece ser boa chave de leitura para "Os feijões", que traz versos como

Nas grandes universidades

O feijão preto não pode ingressar

Será que existem as seleções

Prêto pra cá e branco pra lá

E nas grandes reuniões

O feijão prêto é vedado entrar? (Jesus, 2015, s.p.)

Pedaços da fome (Carolina pretendia chamá-lo A felizarda, um título que acrescenta camadas de ironia à leitura da obra), romance publicado em 1963, é emblemático do que se afirma aqui, na medida 
em que se vincula à perspectiva histórica e crítica antiescravista que recém identificamos, ao tomar como base literária Escrava Isaura para narrar o empobrecimento paulatino de uma moça rica.

O entrecho do romance abolicionista serve como chave para a leitura da passagem do Brasil rural para o Brasil urbano, dando a ver uma retomada crítica e inventiva da tradição disponível. $\mathrm{O}$ personagem Paulo diz para Maria Clara, a protagonista: "Teu pai é severo. Ao lado dele eu fico sem ação. O teu pai tem hábitos de escravocrata. Na sua presença eu tenho a impressão de que estou vivendo na época da escravidão. Eu não posso e não devo ter sinhô. Eu aqui sou rato nas garras do gato" (Jesus, 1963, p. 60). Esse pai e escravocrata é um coronel, que, ao final do romance, está cheio de projetos para o Brasil, inclusive com a ideia de forçar a renúncia do presidente e encaminhar qualquer coisa que não seja uma eleição, já que uma eleição seria "muito cara para um país" (Jesus, 1963, p. 216). É bom dizer de novo: o romance foi publicado em 1963 !

\section{O projeto na prática}

Em 13 de maio de 1958, no Quarto de despejo, Carolina escreveu:

Hoje amanheceu chovendo. É um dia simpatico para mim. É o dia da Abolição. Dia que comemoramos a libertação dos escravos.

... Nas prisões os negros eram bodes espiatorios. Mas os brancos agora são mais cultos. E não nos trata com despreso. Que Deus ilumine os brancos para que os pretos sejam feliz.

Continua chovendo. E eu tenho só feijão e sal. A chuva está forte. Mesmo assim, mandei os meninos para a escola. Estou escrevendo até passar a chuva, para eu ir lá no senhor Manuel vender os ferros. Com o dinheiro dos ferros vou comprar arroz e linguiça. A chuva passou um pouco. Vou sair.

... Eu tenho tanto dó dos meus filhos. Quando eles vê as coisas de comer eles brada:

- Viva a mamãe!

A manifestação agrada-me. Mas eu já perdi o habito de sorrir. Dez minutos depois eles querem mais comida. Eu mandei o João pedir um pouquinho de gordura a Dona Ida. Ela não tinha. Mandei-lhe um bilhete assim:

- "Dona Ida peço-te se pode me arranjar um pouco de gordura, para eu fazer sopa para os meninos. Hoje choveu e eu não pude catar papel. Agradeço. Carolina."

... Choveu, esfriou. É o inverno que chega. E no inverno a gente come mais. A Vera começou a pedir comida. E eu não tinha. Era a reprise do espetaculo. Eu estava com dois cruzeiros. Pretendia comprar um pouco de farinha para fazer um virado. Fui pedir um pouco de banha a Dona Alice. Ela deu-me banha e arroz. Era 9 horas da noite quando comemos.

E assim no dia 13 de maio de 1958 eu lutava contra a escravatura atual - a fome! (Jesus, 1960, p. 27). ${ }^{2}$

A chuva significa para Carolina um problema da maior gravidade. Quando chove, não há papel para catar e ela fica privada de sua principal fonte de renda. Há também certo cuidado para não adoecer, o que colocaria em risco os três filhos. Por fim, a falta de roupas e calçados dificultava sair. Dias chuvosos traziam tristezas, aborrecimentos e preocupações. Impossibilitando catar para conseguir dinheiro, eram, além de tudo, dias que tendiam à fome. Porém, este dia chuvoso é simpático, por ser a data da Abolição, com A maiúsculo.

Carolina faz nesse dia três planejamentos alimentares (nenhum dá certo). Ela sabe que tem feijão e sal. Pretende comprar arroz e linguiça. Ao longo do livro, a linguiça tem duas funções: ser a dose diária de proteína e ser utilizada como substituta de gordura, banha, óleo ou azeite. Desta vez, parece prevalecer a segunda função, já que a busca por gordura é um dos motes da entrada. Sem gordura, fazer comida ficava mais difícil.

Ao saber - depois de os meninos retornarem da escola - que Dona Ida não podia ajudar com gordura, Carolina desistiu da sopa que tinha pensado em fazer.

Na passagem entre o tema da abolição e o das relações entre brancos e negros, houve uma aparente associação entre assuntos. Em Quarto de despejo isso é muito comum. No caso da entrada

${ }^{2}$ As reticências estão no original. 
que estamos interpretando, a ideia de fazer sopa pode ser associada à ideia, correlata na nossa cultura, de inverno, estação que, contudo, exige mais calorias. Nesse caso, novo deslizamento faz surgir a ideia de um virado com farinha: talvez assim a fome fosse resolvida por um tempo, agora que o inverno chegava e se faziam necessários pratos com mais "sustança". A passagem de um assunto a outro geralmente não é explicada ou mediada, levando à impressão de uma escritora que deixa a escrita ir jorrando e produzindo seus choques, como se fosse movida por determinações de fora para dentro. Daí, talvez, o efeito de depoimento autêntico de que fala Audálio Dantas no prefácio da obra e que muitos leitores endossam. Efeito também de imediatismo ou pouca estruturação. Todavia, efeito é uma coisa, composição é outra.

O tipo de associação semântica a que me referi era elogiada, no mesmo ano do início de produção do diário publicável, 1955, num estudo de Othon Moacyr Garcia, Esfinge Clara: palavrapuxa-palavra em Carlos Drummond de Andrade, que desde o título evidencia um dos métodos de construção do grande poeta mineiro, nesse quesito, próximo aos métodos da sua conterrânea. Associações mais explícitas acontecem em outros momentos de Quarto de despejo, em que talvez se possa falar de um uso consciente de paronomásias.

Finalmente Dona Alice dá para Carolina um pouco de banha e arroz. São nove horas da noite. Finalmente os meninos comem. E Carolina se pensa como alguém que luta contra a escravatura atual, isto é, a fome.

Para interpretar esse último trecho, o círculo hermenêutico pode se abrir e abranger Diário de Bitita. Se está correta a hipótese de que Carolina pesquisou e organizou uma tradição abolicionista e negra na qual procurou se inscrever, então é correto dizer que, ao associar, nesse trecho, a fome contemporânea à escravidão, ela efetiva um projeto estético e intelectual. Isso é feito a partir de uma escrita que só podia se realizar "até passar a chuva", ou seja, uma escrita vinculada à contingência, o que é diferente de dizer que fosse determinada unicamente pela contingência. De manhã, Carolina não sabia a que horas iria comer, se é que iria comer, nem muito menos até que horas iria escrever. Porém, ela sabia muito bem que o sofrimento daquele dia precisava ser narrado a partir de uma perspectiva histórica, reflexiva e crítica, que levasse em conta a escravidão e as lutas antiescravistas.

A dialética entre projeto intelectual e contingência pode ser melhor entendida quando se observa o tempo da narração em Quarto de despejo. Nessa entrada do diário, temos pelo menos quatro momentos referentes ao tempo da narração:

1) Hoje amanheceu chovendo.

2) Continua chovendo.

3) .... Eu tenho tanto dó dos meus filhos.

4) Choveu, esfriou. É o inverno que chega.

A variedade dos tempos da narração é característica do gênero diário, mas em Quarto de despejo ela aparece com uma intensidade incomum. A forma da escrita é entrecortada pelo cotidiano atribulado, a tal ponto que talvez se possa afirmar que o livro seja entre outras coisas uma escrita a respeito da interrupção da escrita: "eu estava escrevendo quando...", afirma Carolina ao longo de boa parte do livro. Com o perdão do trocadilho, é mais ou menos como se as condições de escrita se entrecruzassem com um projeto de escrita das condições. A multiplicidade temporal sugere tempos mediados (a vontade de escrever ordenada pelo sujeito) e tempos imediatos (as interrupções que acossam o sujeito). A forma de Quarto de despejo comporia, portanto, uma tensão entre um sujeito que ordena o cotidiano pela mediação de um projeto intelectual e o imediato da necessidade, da percepção, da interrupção da escrita.

A variedade de tempos de narração fica ainda mais complexa quando o tempo do narrado recebe nossa atenção. Carolina escreve enquanto chove. É manhã. Os meninos vão para a escola. Carolina escreve e quando a chuva passa, ela sai. Carolina e as crianças voltam. Ela escreve um bilhete para Dona Ida, pedindo gordura. João entrega o bilhete. Vera pede comida. Carolina pede banha para Dona Alice. Alice oferece banha e arroz. Carolina prepara comida. A família come às $9 \mathrm{~h}$ da noite. Carolina escreve. 
Três reflexões são inseridas em meio a essas atividades cotidianas: uma sobre a relação de brancos e negros (em que a questão do aprisionamento injusto reaparece), outra sobre os sentimentos de Carolina a respeito da fome dos filhos e a última sobre a escravatura atual e a luta de Carolina.

O dia-a-dia de fome e trabalho evoca reflexões. As reflexões inserem o dia-a-dia na história dos negros que lutaram contra a escravatura e daqueles que continuam lutando contra a escravatura, depois de terem sido bodes expiatórios. Mais uma vez o tempo imediato das necessidades alimentares é narrado por uma perspectiva histórica, reflexiva e crítica. Ao longo do diário há dezenas de trechos com narrações inseridas, que remetem à história da carestia nos anos 1950, à vida de Carolina, ao racismo nos Estados Unidos, entre outras questões.

Está evidente que o significado das palavras chuva, linguiça, fome e escravatura precisa ser decidido levando-se em conta o livro como um todo e, se possível, outros livros de Carolina. Até mesmo a palavra feijão se desdobra em camadas sobre as quais não é o momento de dissertar. Ler essas palavras - chuva, linguiça, feijão, fome e escravatura - pensando no seu significado corrente leva a um enfraquecimento dos sentidos construídos pelo livro. Elas ficam mais vazias, menos simbólicas, menos multifacetadas. Portanto, o significado delas é em grande parte construído pela lógica interna do livro, pela estrutura do livro, o que indica que ele pode ser entendido como um mundo em si mesmo, com leis de significação muito próprias, singulares, sem deixar de ser uma apreensão constante de dilemas cotidianos, contingentes. Que escrita é essa, capaz de dar a impressão de que a vida está se passando ao vivo diante dos nossos olhos, quase sem mediação, e, ao mesmo tempo, inscrever cada pequeno acontecimento numa história mundial, mediada, meditada e formulada ao longo de uma vida inteira de reflexões e estudos?

Literatura para Carolina parece remeter a uma forma capaz de ligar fome com escravidão, desde a perspectiva da história de lutas antiescravistas, principalmente aquelas empreendidas por negros. Nisso se prende um dos efeitos de singularização dos sentidos das palavras que recém listei. $\mathrm{O}$ principal, ao menos do ponto de vista deste ensaio, é que o imediato da necessidade não determina totalmente a escrita, que, como se viu, é um projeto de longo prazo, mediado por temas e problemas que se condensam numa perspectiva histórica, reflexiva e crítica formulada a partir do estudo de uma tradição de pensadores, políticos, intelectuais e literatos. Ao mesmo tempo, o imediato da necessidade está presente em diversos aspectos da escrita, desde seu ritmo que vai encadeando associações, até o seu tom.

Até aqui, verifiquei a existência em Quarto de despejo de um projeto de livro "publicável" que se formulou como parte de um projeto intelectual mais amplo. Isso pode dar a impressão de que Carolina era uma pensadora onisciente. Ao contrário, também ela, como todos, percebia certas questões e não outras. Houve para ela zonas inconscientes.

\section{O mutirão}

Quando Antonio Candido pesquisou os caipiras em Os parceiros do Rio Bonito - cuja redação foi concluída em 1954, meses antes do início da escrita do diário de Carolina - reparou que a prática do mutirão estava se modificando. Antes, o mutirão era um dia de trabalho e de festa, em que os participantes trocavam horas de serviço, sobretudo em colheitas. Ao final, o caipira beneficiado pelo trabalho da comunidade oferecia comida e bebida, além de ficar comprometido a fazer mutirão quando chamado.

Repentinamente, porém, os caipiras se viram prensados pelo tempo capitalista, a que se ligavam pelos mercados das redondezas e pela lógica dos latifúndios em que trabalhavam à meia ou parceria. Sem tempo e precisando fazer render o próprio trabalho, deixaram de praticar os mutirões, que, por volta de 1954, reduziam-se a cooperações entre familiares, muitas vezes sem a devida paga em comida e bebida, tal a pobreza de quem necessitava da ajuda (às vezes velhos doentes). Nesse período também se modificou uma prática em torno da caça, tão apreciada pelos parceiros. Com a tomada das terras pelo latifúndio, as caças rarearam. Assim, enquanto até por volta dos anos 1940 era comum um caipira dividir caças com os vizinhos próximos, a partir dos anos 1950 isso se tornou menos frequente. Antonio Candido ia assistindo às modificações sociais daquele período e temia 
que a individualização do caipira resultasse na sua cooptação pela lógica urbana. Na cidade, o caipira analfabeto e sem treinamento para trabalhos específicos, tenderia a passar fome e dificuldades. Na roça, ele já tinha sido expropriado de seus saberes na fabricação de utensílios, preparação de alimentos e remédios, festas e cuidados.

Há grande proximidade entre essa narrativa sociológica e a narrativa memorialística de Diário de Bitita, que narra a viagem de Carolina e sua mãe entre a expulsão de Sacramento, após a prisão, e a chegada a São Paulo (tema aliás retomado em Pedaços da fome, mas, dessa vez, por um sutil mecanismo de vingança narrativa, vivido pela filha de um fazendeiro rico, que sai do interior e vai passar fome em São Paulo). O mundo ficcional de Carolina é uma complexa interpretação do Brasil. Senão vejamos.

Quarto de despejo foi escrito em 1955, 1958, 1959 e 1960, portanto é contemporâneo das modificações pesquisadas por Candido. Em 20 de julho de 1958, três homens, Adalberto, Luiz e o José da Dona Rosa, trabalharam numa cerca em torno da casa de Carolina na favela do Canindé (Jesus, 1993, p. 85-88). A cerca tinha o propósito de evitar a entrada de nortistas no terreno, que, segundo Carolina, bastante preconceituosa a esse respeito, aborreciam-na. Carolina fez almoço para os três trabalhadores, que acrescentaram por conta própria pinga à refeição. Ela então preparou caipirinha.

No ano seguinte, em 5 de maio, chegou a hora de matar um porco que Carolina engordara, à meia. Orlando Lopes matou o porco, Carolina preparou tudo, da fervura da água até a instalação de uma trempe de tropeiro. Depois de morto o porco, ela recolheu o sangue para fazer chouriço e teve especial cuidado em reservar a preciosa banha, que, cuidadosamente utilizada, duraria até julho. Meio porco devia ser dado ao dono, o irmão de seu Manoel, o mesmo Manoel namorado querido por Carolina. Outra metade ficou para Carolina. Dessa metade, um pedaço se destinou a Orlando. Logo apareceram vizinhos pedindo outros nacos. Um tal Chiclé queria as tripas; Maria, mãe da Anália, queria comprar toucinho. Carolina temeu que os vizinhos invadissem seu quintal e roubassem o porco. "Se eles invadir, adeus barraco".

O trecho do diário a respeito do porco, impressionante sob qualquer perspectiva, foi aqui somente parafraseado. Ele traz uma diferença importante em relação ao primeiro trecho analisado, o de 13 de maio de 1958. Notou-se que a estrutura do primeiro tem uma elaboração baseada numa perspectiva intelectual construída a longo prazo e calcada numa tradição. Aqui, por outro lado, é como se a tradição do mutirão e seus rituais estivesse se esvaindo pouco a pouco ou, se quisermos, transformando-se em outra coisa. Vamos supor que sim: o mutirão e a partilha da carne se tornaram outra coisa e Carolina precisou se esforçar para dar nome a esse processo. Há um processo de isolamento, de individualização ou, para usar uma palavra de Carolina, metalização ou monetarização, que, de outra perspectiva, significa abandono e vulnerabilidade de multidões. A inscrição da narrativa sobre o porco na perspectiva intelectual que identificamos é mais imprecisa, embora ainda exista. Digamos que o drama da sobrevivência imediata é aqui estruturado por práticas e representações que estavam se tornando inviáveis. Desta vez, a perspectiva histórica está presente sem estar necessariamente na consciência do projeto de escrita. Todavia, as relações entre os assuntos e o andamento das ações é mais cosido. A própria ligação sintática é mais explícita. A tal ponto que se diria que construir uma narrativa na qual se avizinham a fome e a escravidão exige esforços que chegam a desmanchar as ligações lógicas entre os significantes, enquanto se afastar da perspectiva histórica em direção a um quadro de individualização parece ser "natural" para a forma. Assim, lá onde Carolina realizava seu projeto de escrita, sua escrita se desfazia; lá onde ela perdia o projeto por momentos, sua escrita corria firme, épica.

Ficam dessa maneira delineados dois elementos fundamentais para pensar como se dá a criação literária de Carolina em Quarto de despejo (e, talvez, em diversos de seus livros). 1) Um projeto de inserção de si numa longa tradição de autores antiescravistas, críticos do preconceito racial e 2) uma escrita aberta e atenta aos efeitos no inconsciente dos processos de transformação social.

Fixados esses dois pontos, talvez seja possível sintetizar em um parágrafo o que encontramos até agora: Quarto de despejo é um esforço da escritora de tornar publicável (literatura) o que ela considerava impublicável (diários, cadernos). Para isso, Carolina se vale de um longo acúmulo de reflexões sobre uma tradição crítica de intelectuais e escritores. Nessa tradição encontra formas de 
organizar em figuras de uma perspectiva histórica, reflexiva e crítica o material que vai identificando no seu criterioso inventário do dia-a-dia de São Paulo. Parte do material inventariado em seu diário apresenta conteúdos inconscientes, que, não obstante, Carolina, por meio de associações e condensações, vai formulando e, por assim dizer, trazendo para o mundo da palavra. Outra parte diz respeito a um projeto consciente e duradouro, que é dela, mas é também de mais ou menos cinco gerações de intelectuais negros.

\section{A fome}

Como a poesia e a fome, a criação artística e a miséria urbana, foram articuladas por Carolina? Como esse projeto intelectual deu forma ao que, com tanta dificuldade, ganhava forma nos estudos sobre o Brasil? (Lembrando que livros como Geografia da fome, de Josué de Castro, datam de meados dos anos 1940).

Além das brigas entre casais, outras das "pornografias" que tiravam, ao serem relatadas, o que Carolina chamou de "donaire do livro" (Jesus, 1996, p. 80), ou seja, a possibilidade de ser publicado, eram a miséria e a violência. O principal aspecto dessa questão é a fome. Portanto, cabe perguntar como Carolina ficcionaliza a fome.

Quarto de despejo é provavelmente um dos livros da literatura brasileira em que mais aparecem referências à alimentação. Aproximadamente 133 alimentos diferentes são nomeados nas cento e cinquenta e poucas páginas da edição que consultei. Aqui está uma lista das referências a pão, carne e leite: pão, pão doce, pão mole, pão duro, pão com perna de barata; carne, carne com farinha, carne do lixo, carne moída, carne para bife, bife, filé, carne assada, carne podre, peixe, cabeça de peixe, bacalhau, sardinha, porco, cabeça de porco, chouriço, tripas, toucinho, barrigada, lombo, bofe, torresmo, ossos de porco, miúdo de vaca, bucho, fígado, coração, frango, salsichas do lixo, salsichas, linguiça, linguiça enlatada; leite e Toddy.

Além de viver com fome em meio a uma impressionante variedade de alimentos, Carolina também vive faminta em meio a uma grande quantidade de alimentos. Ao longo de suas andanças, ela passa por uma fábrica de pudim (ou doces) e outra de biscoito; um frigorífico, açougues, supermercados, armazéns de estoque, caminhões carregados com comida. É uma infinidade de alimentos sendo produzidos, circulando e sendo consumidos, quando não descartados. Há muita coisa apodrecendo em armazéns, depois descartada no rio Tietê ou em qualquer canto. Em meio a tanta comida, a fome aparece praticamente em todas as páginas, principalmente ao longo das entradas dos anos de 1958 e 1959.

A complexidade da obra tem outras facetas também, além desse curto-circuito. Nas suas páginas, figuram temas como violência, alcoolismo, casamento, suicídio, tristeza, política, trabalho, preconceito racial, escrita, leitura, cultura de massa (rádio, cinema, gibi) entre outros, e formas como o diálogo, a descrição, o poema, a letra de samba, o devaneio diurno, o relato de sonhos, a reportagem, a manchete, a diatribe, a narrativa.

Carolina estudou dois anos numa escola espírita em Sacramento, Minas Gerais, de onde saiu com a mãe, numa caminhada de fazenda em fazenda, sequência de racismo, machismo, superstição e falta de espaço entre latifúndios, até chegar a São Paulo, sozinha. Instrução precária, êxodo rural e fome formam um horizonte social do qual ela tomava consciência pouco a pouco. E ela o faz, por fim, em São Paulo, na favela do Canindé, entre 1947 e 1960. Carolina deseja ser poeta. Portanto, a ideia de uma perspectiva histórica, reflexiva e crítica se imbrica a essa outra.

Apesar da incongruência entre a vida que leva e as necessidades que reconhece serem intrínsecas à poesia, Carolina permanece com o firme propósito, dia após dia, de dar uma forma literária para o caos vivido.

A esse respeito um breve comentário dos seguintes trechos trará os elementos de que preciso para seguir com a argumentação. 
... O Adalberto errou o quarto. Em vez de entrar no dele entrou no quartinho da Aparecida. E os favelados queriam retirá-lo de lá, porque se o Negrão chegasse havia de espancá-lo. Eu fui retirá-lo de lá porque ele me obedece. Resolveu sair. Quando eu fui deitá-lo, ele disse: - Sabe, Carolina, eu sou um homem infeliz. Depois que morreu Marina nunca mais ninguem me quiz.

Eu dei uma risada, porque percebi que ele havia falado e formado uma quadrinha. Parei de rir, porque a tristeza de sua voz comoveu-me. Marina foi uma mulher negra que viveu com ele. Bebia muito. E morreu tuberculosa com 21 anos (Jesus, 1993, p. 147).

2

... Hoje tem muito papel no lixo. Tem tantos catadores de papeis nas ruas. Tem os que catam e deitam-se embriagados. Conversei com um catador de papel.

- Porque é que não guarda o dinheiro que ganha?

Ele olhou-me com o seu olhar de tristeza:

- A senhora me faz rir! Já foi o tempo que a gente podia guardar dinheiro. Eu sou um infeliz. Com a vida que levo não posso ter aspiração. Não posso ter um lar, porque um lar inicia com dois, depois vai multiplicando.

Ele olhou-me e disse:

- Porque falamos disso? O nosso mundo é a margem. Sabe onde estou dormindo? Debaixo das pontes. Eu estou doido. Eu quero morrer!

- Quantos anos tem?

- 24. Mas já enjoei da vida.

Segui pensando: quem escreve gosta de coisas bonitas. Eu só encontro tristezas e lamentos (Jesus, 1993, p. 161).

Nos dois casos, Carolina acolhe palavras que ouve no dia-a-dia e as pensa em termos literários. No primeiro, percebe que a fala de um viúvo triste caberia numa quadrinha: “- Sabe, Carolina, / eu sou um homem infeliz. / Depois que morreu Marina / nunca mais ninguem me quiz".

No segundo, escuta o desalento de um jovem que enjoou da vida. Conclui que era um material difícil de tornar literário, pois quem escreve gosta de coisas bonitas. Esse tipo de reflexão é um mote do livro: "Eu estou triste", escreve Carolina. E completa: "Deus devia dar uma alma alegre para o poeta" (Jesus, 1993, p. 121). Ou ainda: "Se o padre morasse na favela se expressaria de outra forma" (Jesus, 1993, p. 126). Ou ainda, um pouco antes, encontra um sapateiro que pergunta se ela escreve um livro comunista. Ela responde que é um livro realista. E ele completa: "Não é aconselhável" (Jesus, 1960, p. 96). Trechos equivalentes aparecem em praticamente todo Quarto de despejo. Uma das regularidades parece ser a seguinte: a escritora pensa encontrar um tipo de matéria à qual a literatura ou a expressão "civilizada" do padre não tem como dar forma.

\section{Primitividade}

Nesse ponto, surge para nós o problema mais explícito para a criação poética de Carolina. Os poetas de salão, como ela os classifica, não têm instrumentos para pensar o mundo desde a perspectiva do quarto de despejo, embora tenham os instrumentos para escrever bonito. Por outro lado, os poetas do lixo precisam lidar com um tipo de regressão social que os desafia, na medida em que estão sofrendo um processo de afastamento de suas bases culturais e materiais, que também é de exclusão das bases culturais e materiais da vida urbana, supostamente civilizada. Contrastando esses extremos, Carolina chega à conclusão de que ocorre um "retorno à primitividade", marcado pela fome, angústia, marginalização, retorno de práticas ineficazes diante dos novos problemas (chás para resolver vermes), animalização. Os trechos seguintes exemplificam os pontos trazidos. Eles mostram também a consistência do diagnóstico social feito por Carolina. De modo algum se trata de algo "impensado" ou "imediato". A ideia de um retorno à primitividade é retomada constantemente, sendo uma espécie de motivo do livro, o que demonstra mais uma vez (agora em outro nível) que o material bruto do dia-a-dia era constantemente traduzido para servir como elemento de elaboração de alguns problemas. Por outro lado, compare-se o segundo trecho recém citado com o quarto trecho, a seguir, a respeito do tema da "margem". Depois dos trechos, que 
acabam se tornando exemplos complementares dos argumentos até aqui expostos, proporei uma análise e endereçarei uma conclusão.

3

Para mim o mundo em vez de evoluir está retornando a primitividade. Quem não conhece a fome há de dizer: 'Quem escreve isso é louco'. Mas quem passa fome há de dizer:

- Muito bem, Carolina. Os generos alimenticios deve ser ao alcance de todos (Jesus, 1993, p. $34)$.

4

... Nós somos pobres, viemos para as margens do rio. As margens do rio são os lugares do lixo e dos marginais. Gente da favela é considerado marginais. Não mais se vê os corvos voando as margens do rio, perto dos lixos. Os homens desempregados substituiram os corvos.

Quando eu fui catar papel encontrei um preto. Estava rasgado e sujo que dava pena. Nos seus trajes rotos ele podia representar-se como diretor do sindicato dos miseraveis. O seu olhar era um olhar angustiado como se olhasse o mundo com despreso. Indigno para um ser humano. Estava comendo uns doces que a fabrica havia jogado na lama. Ele limpava o barro e comia os doces. Não estava embriagado, mas vacilava no andar. Cambaleava. Estava tonto de fome! (Jesus, 1993, p. 48).

5

... O José Carlos está melhor. Dei-lhe uma lavagem de alho e um chá de ortelã. Eu zombei do remedio da mulher, mas fui obrigada a dar-lhe porque atualmente a gente se arranja como pode. Devido ao custo de vida, temos que voltar ao primitivismo. Lavar nas tinas, cosinhar com lenha.

... Eu escrevia peças e apresentava aos diretores de circos. Eles respondia-me:

- É pena você ser preta.

Esquecendo eles que eu adoro a minha pele negra, e o meu cabelo rustico. Eu até acho o cabelo de preto mais iducado do que o cabelo de branco. Porque o cabelo de preto onde põe, fica (Jesus, 1993, p. 58).

6

Quando eu passava na Avenida Tiradentes, uns operarios que saíam da fabrica disse-me:

- Carolina, já que você gosta de escrever, instiga o povo para adotar outro regime.

Um operario perguntou-me:

- É verdade que você come o que encontra no lixo?

- O custo de vida nos obriga a não ter nojo de nada. Temos que imitar os animaes (Jesus, 1993, p. 100).

7

... Eu cancei de escrever, adormeci. Despertei com uma voz chamando Dona Maria. Fiquei quieta, porque não sou Maria. A voz dizia:

- Ela disse que mora no numero 9.

Levantei de mau humor e fui atender. Era o senhor Dario. Um senhor que eu fiquei conhecendo na eleição. Eu mandei o senhor Dario entrar. Mas fiquei com vergonha. $\mathrm{O}$ vaso noturno estava cheio.

... O senhor Dario ficou horrorizado com a primitividade em que eu vivo. Ele olhava tudo com assombro. Mas ele deve aprender que a favela é o quarto de despejo de São Paulo. E que eu sou uma despejada (Jesus, 1993, p. 129).

A civilização como processo indica um caminho de retorno à primitividade, portanto a civilização na verdade reproduziria aquilo que alegava superar. O primitivo é para Carolina resultado de um processo da civilização e não a característica de alguns povos ainda não integrados na civilização, como era comum se pensar na sociologia da época. Para estancar o retorno ao primitivo causado pela civilização seria preciso uma perspectiva adequada, que só quem passa fome poderia trazer. 
Em resumo, há muita estruturação, isto é, muita "forma literária" em Quarto de despejo, assim como acontece, de maneiras diversas, em inúmeros dos demais manuscritos e datiloscritos ainda não publicados, que, entendidos como um todo, dão a ver uma poética (Fernandez, 2018). Que estruturas são essas? A primeira é a estrutura que inscreve Carolina na tradição culta antiescravista. A segunda é o projeto de um livro que se vai fazendo enquanto o lemos, numa difícil transformação do impublicável em publicável. A terceira é a estrutura que inscreve os eventos cotidianos no, digamos assim, progresso do regresso. Outra é a estrutura de poetização do dia-a-dia e da linguagem dos vizinhos. Outra ainda é a estrutura que procura narrar um processo não de todo conscientizado, mas bastante familiar (conhecido não pensado). Elas podem talvez ser todas reduzidas ou condensadas na primeira, o que precisa ser melhor pesquisado. De toda maneira, não vejo como seria possível afirmar que a escrita do diário de Carolina não foi mediada por uma enorme série de processos, uns mais conscientes, outros menos (e aqui inconsciente não tem qualquer acepção negativa).

A escrita literária popular precisa ser acolhida e considerada com mais cuidado do que tem sido. Podemos aprender com ela tanto quanto ou mais do que aprendemos lendo teóricos tão sofisticados como Antonio Candido, um dos primeiros a evidenciar no Brasil uma tradição de pensamento antioligárquico. Em uma entrevista a Beatriz Sarlo, ele afirmou: "[...] parece possível afirmar que a literatura brasileira, embora siga padrões cultos fortemente impostos, e embora tenha contribuído para consolidar o sistema de dominação política e social, possui correntes reprimidas, oriundas seja de padrões mais populares, seja de modelos heterodoxos" (Candido, 2002, p. 112). Carolina, como vimos, pesquisou e produziu uma tradição radical e antioligárquica e, ao escrever, posicionou-se como parte dela, tendo que dar respostas a problemas complexos da vida regressiva brasileira e das possibilidades de produzir cultura nas margens da "civilização". A expressão "quarto de despejo" é um exemplo desse processo de simbolização, que implica a perspectiva histórica, reflexiva e crítica possibilitada pela tradição que Carolina inventou para si. O termo foi observado na linguagem corrente, da qual os anúncios de jornal da época parecem indicar que ia sumindo, e sustentado por um monumental projeto ético e estético. O dia-a-dia da favela nunca aparece imediatamente em Quarto de despejo, mas sempre mediado por essa perspectiva. É um projeto intelectual que merece mais atenção, pois, uma vez delineado, complexifica as maneiras que temos tido de simbolizar o caos da civilização, quer dizer, da ultracivilizada primitividade brasileira.

\section{Referências}

CANDIDO, Antonio (2010). Os parceiros do Rio Bonito: estudo sobre o caipira paulista e a transformação dos seus meios de vida. Rio de Janeiro: Ouro sobre Azul.

CANDIDO, Antonio; DANTAS, Vinicius (2002). Textos de intervenção. São Paulo: Duas Cidades, Ed. 34.

CARVAlHO, Antonio José de; DEUS, João de (1890). Dicionário Prosódico de Portugal e Brasil. Porto, Rio de Janeiro: Lopes \& Cia, Frederico Augusto Schmidt. Disponível em https:/ / bit.ly/33F4ktt. Acesso em: 27 set. 2018 .

CASTRO, Eliana de Moura; MACHADO, Maria Novais da (2016). Muito bem, Carolina!. Belo Horizonte: Editora $\mathrm{C} /$ Arte.

FERNANDEZ, Raffaela (2016). O espólio literário de Carolina Maria de Jesus. Manuscrítica, n. 31, p. 10-26. Disponível em: https:/ / bit.ly/2P1mDDU. Acesso em: 02 out. 2018.

FERNANDEZ, Raffaela (2018). A poética de resíduos de Carolina Maria de Jesus. Brasília: Edições Carolina.

GARCIA, Athon M. (1955). Esfinge clara: palavra-puxa-palavra em Carlos Drummond de Andrade. Rio de Janeiro: São José.

JESUS, Carolina Maria de (1993). Quarto de despejo. São Paulo: Francisco Alves.

JESUS, Carolina Maria de (1963). Pedaços da fome. São Paulo: Aquila. 
JESUS, Carolina Maria de (2014). Diário de Bitita. São Paulo: Sesi Editora.

JESUS, Carolina Maria de (2015). O escravo e os feijões. O menelick $2^{\circ}$. ato. Disponível em: http://www.omenelick2ato.com/artes-literarias/o-escravo-e-os-feijoes. Acesso em: 5 dez. 2019.

JESUS, Carolina Maria de (1996). Meu estranho diário. Organização de José Carlos Sebe Bom Meihy e Robert M. Levine. São Paulo: Xamã.

MEIHY, J. C. S. B.; LEVINE, R. M (1994). Cinderela negra: a saga de Carolina Maria de Jesus, Rio de Janeiro: UFRJ.

\section{Agradecimentos}

Este texto é resultado de discussões realizadas pelo grupo de estudos Marielle - Marxismo e Literatura, da Universidade Federal do Ceará, das quais fizeram parte Agno Monte Gama, Andressa Barbosa, Andressa Moreira, Karina Morais, Rinaldo Viana, Wesley Batista, depois Samuelson Xavier, todos estudantes de Letras, além de Maria Porfírio, estudante de arquitetura. Janaína Tatim e Suene Honorato leram versões preliminares. Agradeço os comentários iluminadores que fizeram. Tenho trabalhado direta ou indiretamente com o texto de Quarto de despejo nas aulas que tenho ministrado nos últimos oito semestres. Portanto, estas linhas também devem muito, em seus eventuais acertos, aos debates com os estudantes dos diversos cursos de Letras da UFC que têm lido Quarto de despejo e outros escritos de Carolina da mesma maneira como ela folheava livros: com cuidado e carinho. 